\title{
Application of Geoinformatics for Site Assessment of Large Scale Organic Agriculture Plot
}

\author{
Pattarapunchai, P.* and Wirojanagud, W. \\ Department of Environmental Engineering, Faculty of Engineering, Khon Kaen University, Khon Kaen \\ 40002, Thailand, E-mail: giskku@gmail.com*
}

\begin{abstract}
To enhance organic agriculture promoted by the Governmental policy, Nong Wang Sok Phra Sub-district, Phon District, Khon Kaen Province, Thailand has designated an organic agriculture plot covering the area of 681.50 hectare. It is, however, necessary to identify the suitable organic agriculture in conjunction with large scale by integrating Geoinformatics and Unmanned Aerial Vehicle. The study process consisted of creating a boundary study area map by topography, georeferencing and Land use classification, validating the study area to verify Land use by video record and field observation, assessing the validated study area/Land use map plot by vector analysis through QGIS to create the potential suitable large scale organic agriculture categorizing as the moderate and the least suitable area 151.82 hectare, 89.93 hectare and 34.05 hectare, being equivalent to $55.05 \%, 32.61 \%$ and $12.35 \%$ of total suitable area, respectively; validating the potential suitable large scale organic agriculture plot by focus group interview based on the most suitable area, processing UAV imagery and parcel maps. The output was the suitable organic agriculture plot accepted by the organic agriculture members, located at Ban Kok Lam Village no.3, covering the area of 20.64 hectare, where was only $13.60 \%$ of the most suitable agriculture area. The large scale criteria could not be attained due to the accepted organic agriculture area was lower than the large scale standard of 48 hectare. By the mean of this study, the most suitable organic agriculture plot of151.82 hectare was available for the large scale organic agriculture plot. That would enable Nong Wang Sok Phra Sub-district to carry on for enhancement of the large scale organic agriculture plot.
\end{abstract}

\section{Introduction}

Currently, the conventional agriculture both small and large scales have utilized chemical fertilizer and pesticides (Riwthong et al., 2017 and Schreinemachers et al., 2017), which potentially affect on soil and water ecosystem as well as health of organic agriculture members (Coda et al., 2015). Data of illness induced by chemical pesticides reported in 2017 was 10,312 patients being equivalent to 17.12 to 100,000 people, which increased from 8,689 patients (14.47 to 100,000 people) recorded in 2016. The highest illness rate was found in Satoon province (144.06 to 100,000 people) followed by Prae Province (127.26 to 100,000 people) and Uttaradit Province (116.98 to 100,000 people), respectively. Based on the number of patients, three provinces had the highest number of patients were Phrae Province (572 patients), Uttaradit Province (536 patients) and Buriram Province (533 patients), respectively. Khon Kaen Province (the study area) had 478 patients being equivalent to 26.53 to 100,000 people (Bureau of Occupational and Environmental Diseases, 2018).

Organic agriculture is, therefore, one of the solution of agriculture that is safe to human health and ecosystem (Annosi et al., 2019). The government, thus, has policy on organic agriculture enhancement with the target set for increasing organic agriculture plots and organic agriculture members; increasing the ratio of organic agriculture market within the country; as well as upgrading the folk way-organic agriculture groups. This would enhance the development of organic agriculture of Thailand toward the regional leader of production, consumption, marketing and service of organic agriculture on the sustainable concept and international acceptance in accordance with the National Organic Agriculture Development Strategy 2017-2021 (Nong Wang Sok Phra Sub-District Administration Organization, Phon District, Khon Kaen Province, 2018).

Concurrently, the large scale agriculture on the plot based approach through the agriculture promotion system has also been encouraged by integration of the line agencies and managing the plot along the supply chain by the plot manager. The purpose of the large scale agriculture plot is to enhance collaboration of organic agriculture members and co-managing in order to establish coproduction and co-sale with the identified market. With the large scale agriculture promotion project, 
the organic agriculture members are able to reduce production cost, increase product/unit as well as qualified products under integration of governmental and private sectors (Ministry of Agriculture and Cooperatives, 2016). Therefore, the determined benefit to the organic agriculture members can be made by integration of large scale plot and organic agriculture farm. This is the rationale of the research study presented herein. In order to enhance organic agriculture, Nong Wang Sok Phra, Phon District, Khon Kaen, Thailand has designated organic agriculture plot covering the area of 1,723.72 rai (681.50 hectare) along the creek. However, a large scale organic agriculture is still required in order to cope with the enhancement of collaboration and co-managing of organic agriculture members on production and marketing as mentioned above. Consequently, this study focused an integration of Geoinformatics and UAV Aerial photography for identification of the suitable large scale organic agriculture plot.

\section{Objective}

The objective is to assess the site for suitable large scale organic agriculture plot using integrated Geoinformatics and UAV Aerial Photography, as well as acceptance of the organic agriculture members.

\section{Materials and Methods}

Study steps for site assessment of the large scae organic agriculture plot using Geoinformatics and UAV Aerial photography are illustrated in Figure 1 , which is subsequently presented.

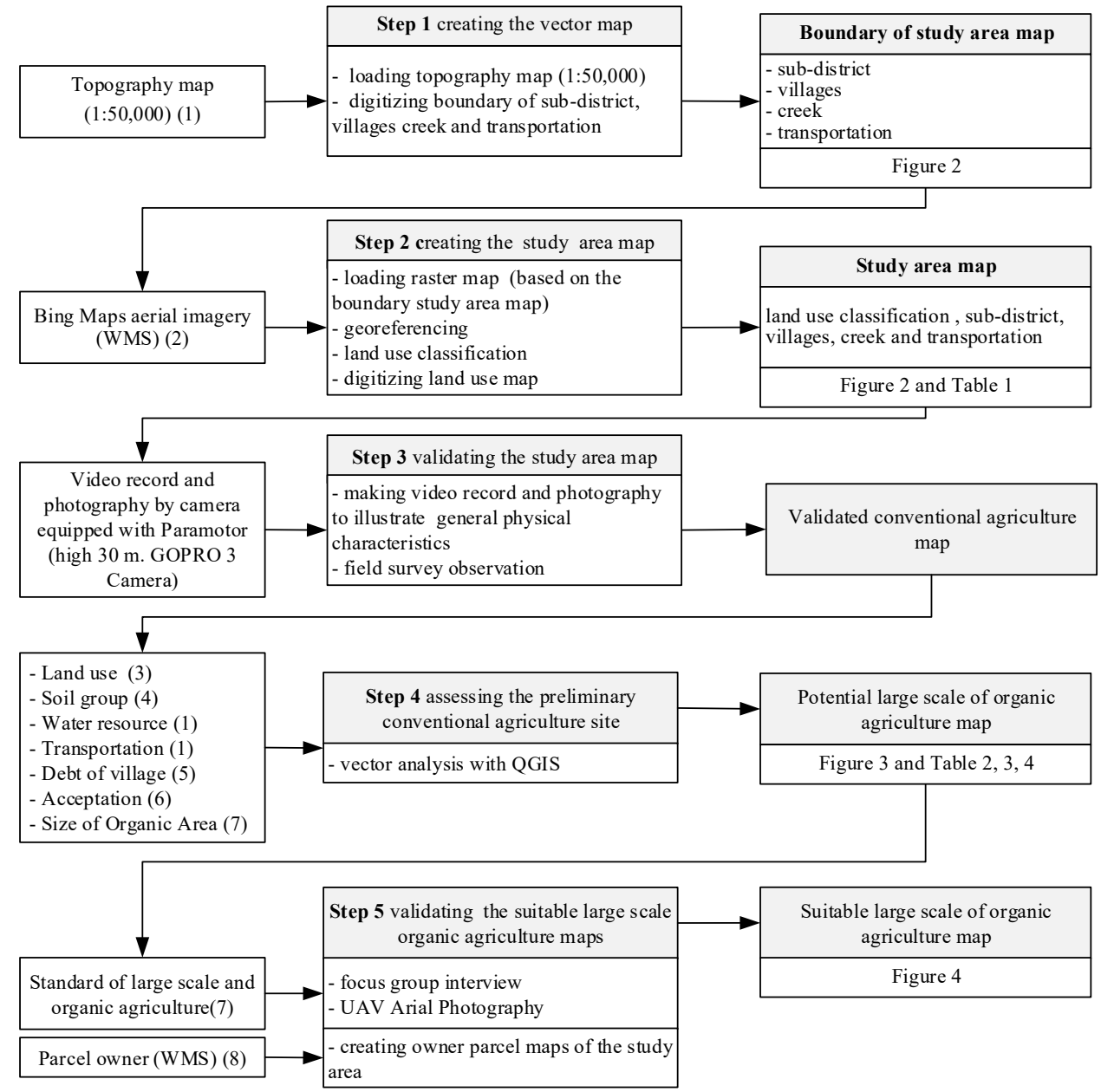

Figure 1: Study Steps for Site Assessment of Large Scale Organic Agriculture Plot

Sources: (1) Royal Thai Survey Department Maps

(2) Microsoft Corporation. https://www.bing.com/maps/aerial

(3) Digitized form Bing Maps aerial imagery web mapping service

(4) Regional Centre Geo-Informatics and Space Technology, Northeast, Thailand.
(5) National Statistical Office of Thailand, Ministry of Digital Economy and Society, Thailand.

(6) Questionnaire

(7) Ministry of Agriculture and Cooperatives, Thailand.

(8) Digitized form WMS of Department of Lands Headquarters Ministry of Interior, Thailand 
tep 1: creating the boundary of study area map was made by loading topography map $(1: 50,000)$ and digitizing boundary of sub-district, villages, creek, and transportation.

Step 2: creating the study area map was made by (1)overlaying the boundary of study area map on the Bing Maps aerial imagery produced the raster map, (2)loading raster map (3)classifying Land use by georeferencing and digitizing.

Step 3: validating the study area map was made by making video record and photography using camera equipped with paramotor, and field survey with observation. The physical characteristics of the study area existed in May 2017 was identified including Huai Luek creek, 7 target villages, Land use, transportation. Noting that the study area was counted at $150 \mathrm{~m}$ north direction from the mid-line of creek. The south direction is belonged to other province where is out of study area.

Step 4: assessing the map of large scale organic agriculture plot (based on the validated study area map or the conventional agriculture map) by vector analysis with QGIS as presented below. Step 4 would create the potential suitable large scale organic agriculture plot.

(1) Designating the factors, indicators, and suitable criteria for large scale organic agriculture plot was made by reviewing the relevant studies and maps.

(2) Weighting of each factor was estimated by averaging the scores taken from 3 means; literature review, participatory process of the agriculture members (called as organic agriculture members) through questionnaire together with Multi-Criteria Analysis (MCA), and researcher judgment by MCA.

(3) Setting the rating score for suitability was ranked as 1-3 equivalent to the least, moderate, and the most suitability, respectively. Each indicator under each factor was performed by the researcher judgment based on the information previously designated in (1).

(4) Estimating suitable score was done using Chapin and Kaiser as equations (1) (Chapin and Kaiser, 1979) by multiplying weighting score of each factor taken from (2) and rating score of each indicator taken from (3)Summation of the multiplied result was total suitable score, which was sorted from the minimum to maximum values. Three suitable intervals were set as the most (S3), moderate (S2) and least (1) suitable land. Suitable interval value was calculated by equation 2. Which create the potential suitable area for large scale organic agriculture plot map.

$$
\mathrm{S}=\mathrm{W}_{1} \mathrm{X}_{1}+\mathrm{W}_{2} \mathrm{X}_{2}+\mathrm{W}_{3} \mathrm{X}_{3}+\ldots .+\mathrm{Wn} \mathrm{X}_{\mathrm{n}}
$$

Equation 1

where,

$\mathrm{S}=$ Total suitable score, $\mathrm{W}=$ Weighting score, $\mathrm{X}_{\mathrm{n}}$

$=$ Rating score

Suitability interval value $=\underline{\text { Maximum suitable value }- \text { Minimum suitable value }}$ Number of suitable interval

Equation 2

(5) Validating the potential suitable large scale organic agriculture plot to confirm the suitable large scale organic agriculture plot:

(5.1) Focus group interview with organic agriculture members was carried out to appraise the acceptance of large scale organic agriculture plot employing the most suitable organic agriculture plot together with the standard of organic agriculture and large scale plot.

(5.2) UAV aerial photography by:

- site selected for flight recording covered only the accepted study area obtained through focus group interview.

- ground control point for13 points (Martínez-Carricondo et al., 2018, Midatana et al., 2018 and Tahar, 2013) was performed by creating ground control targets (size $2 \times 2 \mathrm{ft}$.).

- recording geographic coordinate systems at ground control points was made with GNSS.

- flight planning was set through flight control program of UAV DJI GO high $300 \mathrm{ft}$. front overlap $80 \%$ and side overlap $60 \%$.

- UAV image processing was undertaken by Agisoft PhotoScan 1.4.5 Professional Edition software import coordinate system form GNSS to image processing Geometric correction and image to map rectification.

- creating owner parcel maps of the accepted study area was made to 
identify the land owners by creating virtual raster parcel data by loading raster data and Georeferencing and digitized imagery parcel owner on web mapping service to vector data.

The output of step 5 shows the accepted suitable area for large scale organic agriculture plot exhibited in Figure 4.

\section{Results and Discussion}

This research had employed Geoinformatics and UAV Aerial photography as the main tools to assess the site of large scale organic agriculture plot. The study method was performed step by step as above mentioned. The output or result of each step is consequently described. The output of step 1 was the boundary of study area map (Figure 2) including creek namely Huai Luek, 14 villages located in Nong Wang Sok Phra Sub-districts, and 7 villages (out of 14 villages) owned agriculture area located along the creek were considered as the target villages of the Sub-district for transformation of the conventional agriculture plot to be the organic agriculture plot. For this study, such conventional agriculture area of 7 target villages was thus scoped for large scale organic agriculture plot. The output of Step 2 was study area with Land use map (see Figure 2). Land use of the study area was classified as paddy field, forest plantation, field crop, horticulture and water source as stated in Table 1.

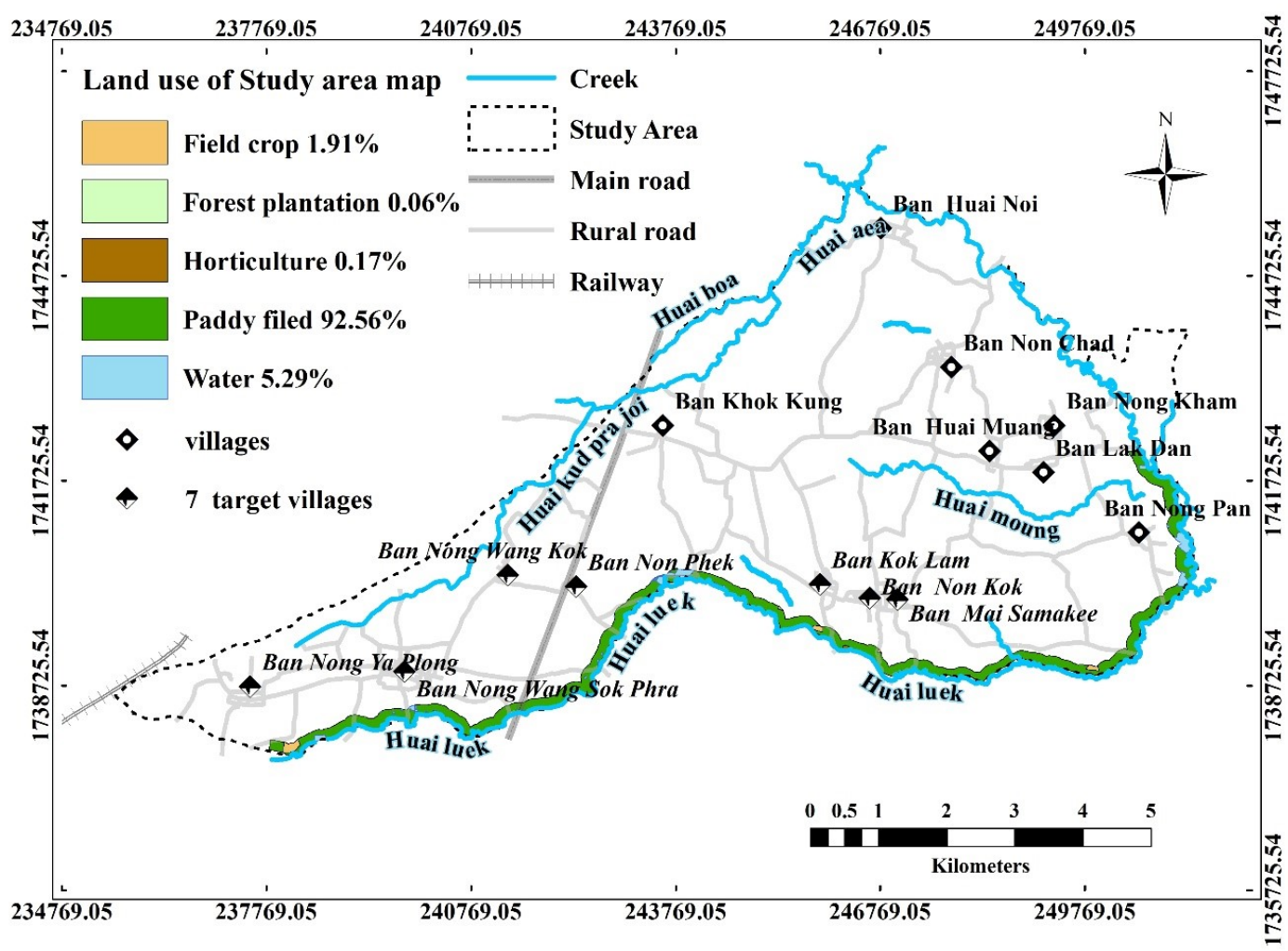

Figure 2: Boundary and study area with land use map

Table 1: Land use of Study Area

\begin{tabular}{|c|c|c|c|}
\hline \multirow{2}{*}{ Land use } & \multicolumn{3}{|c|}{ Area } \\
\hline & rai & hectare & percentage \\
\hline 1.Paddy filed & $1,595.55$ & 630.83 & $92.56 \%$ \\
\hline 2.Forest plantation & 1.10 & 0.43 & $0.06 \%$ \\
\hline 3.Field crop & 32.91 & 13.01 & $1.91 \%$ \\
\hline 4.Horticulture & 2.99 & 1.18 & $0.17 \%$ \\
\hline 5.Water & 91.17 & 36.05 & $5.29 \%$ \\
\hline Total & $1,723.72$ & 681.50 & $100 \%$ \\
\hline
\end{tabular}




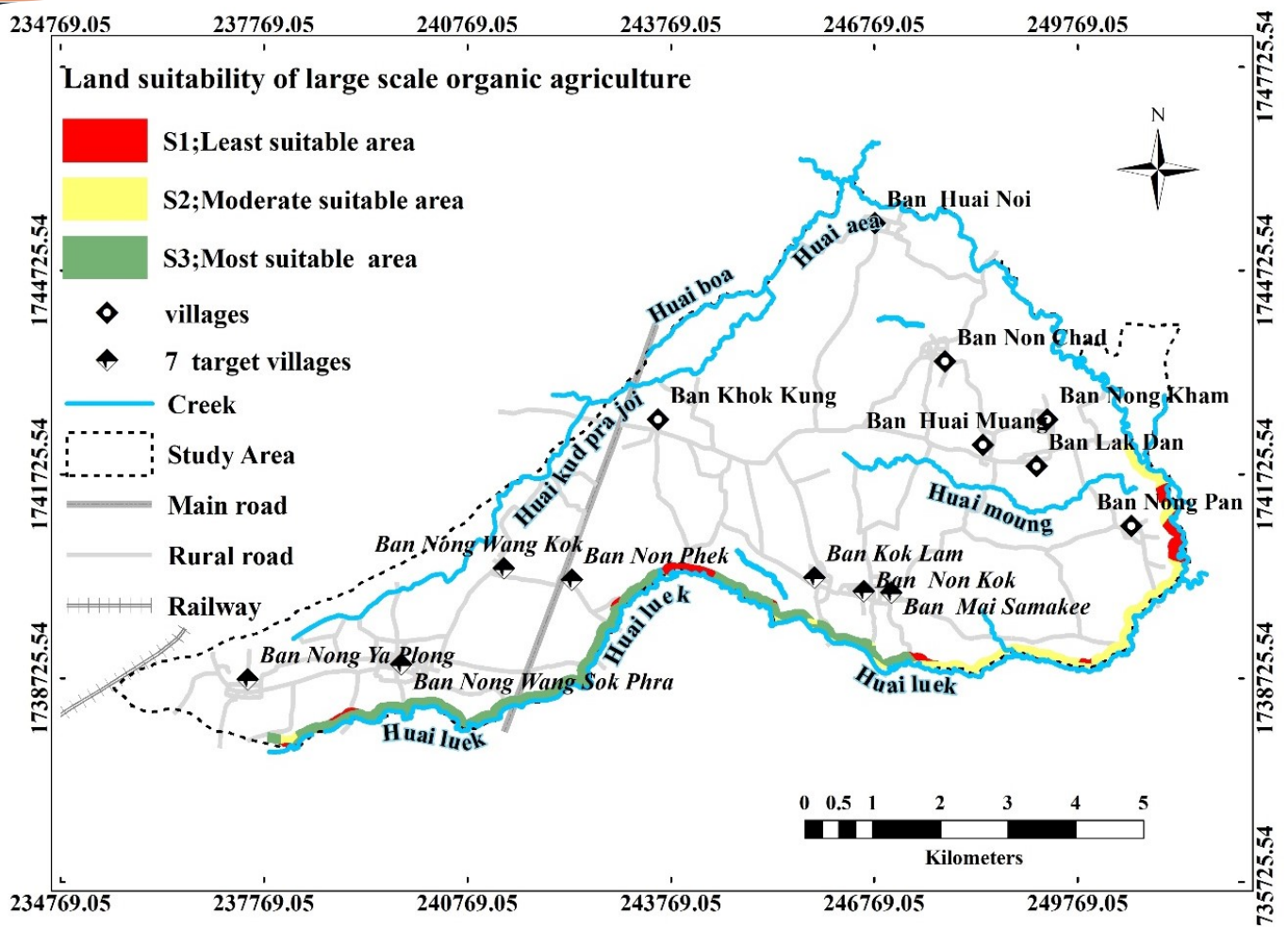

Figure 3: Potential land suitability of large scale organic agriculture

It illustrated the main Land use as paddy field of 630.83 hectare being equivalent to $92.56 \%$ of the total study area (681.5 hectare). Figure 2 presents the green color of paddy field along the creek, while other Land uses are likely difficult to see due to such Land uses occupied very small area compared to the paddy field area. Step 3 was to validate the study area/Land use map by video record and photography and field survey observation. Physical characteristics of the study area existed in May 2017; the creek namely Huai Luek fulfilled with water along the stream for $22 \mathrm{~km}$ distance; agriculture area of 7 villages of 630.83 hectare was mainly paddy field considered as conventional agriculture plot. Such conventional agriculture plot could be evidently seen as green mark in Figure 3. Other Land use types could be validated by photography and observation, but it is not evidently seen by Land use classification as it is hindered by paddy field.

Step 4 was to assess the land suitability for large scale organic agriculture plot. Firstly, factors, indicators, and suitable criteria for large scale organic agriculture plot were identified as shown in Table 2. Secondly, weighting scores were assessed by 3 means including MCA analysis undertaken by organic agriculture members through questionnaires and researchers, and reviewed by the relevant studies. Example of MCA performed by organic agriculture members is illustrated in Table 3. The averaged weighting scores are presented in Table 4. Noting that the weighting scores assessed by the organic agriculture members through questionnaires and the study researchers' judgment were similar, ie. 0.08-0.17 and 0.06-0.18, respectively. However, the weighting scores reviewed from the relevant studies were not similar but were in the same trend. The higher weighting scores were for water resource, acceptance and soil, while transportation was the lowest weighting score. The averaged weighting scores were 0.23 for water resource, 0.17 for each indicator including organic agriculture, debt of villagers, acceptance. Weighting scores were 0.14 for soil, 0.11 for Land use and only 0.06 for transportation. Obviously, the higher weighting scores were the indicators that were directly related to the agriculture production including water resource, organic agriculture, social aspects (acceptance of organic agriculture members and debt of villagers). Soil and Land use were the medium criteria scores as they were moderately related to agriculture production. Transportation was the minor weighting score as it might be the factor that was lower related to agriculture production. The output of step 4 was the potential suitable large scale organic agriculture plot. 
Table 2: Factor, indicator, and criteria for large scale organic agriculture plot

\begin{tabular}{|l|l|l|l|}
\hline \multicolumn{1}{|c|}{ Factor } & \multicolumn{1}{|c|}{ Indicator } & \multicolumn{1}{c|}{ Suitable criteria } & \multicolumn{1}{c|}{ Data use } \\
\hline Land use & $\begin{array}{l}\text { Suitable level taken from land } \\
\text { use }\end{array}$ & $\begin{array}{l}\text { Suitable score taken } \\
\text { from Land use }\end{array}$ & Land use map \\
\hline Soil & Suitable level of soil & $\begin{array}{l}\text { Suitable score taken } \\
\text { from soil series }\end{array}$ & Soil series map \\
\hline Water resource & $\begin{array}{l}\text { Score of catchment } \\
\text { area }\end{array}$ & Water resource map \\
\hline Transportation & $\begin{array}{l}\text { Distance access to main road } \\
\text { and minor road, railway line }\end{array}$ & $\begin{array}{l}\text { Score of distance } \\
\text { (near or far) access to } \\
\text { road }\end{array}$ & Road map \\
\hline Organic area & $\begin{array}{l}\text { Size of organic area of } \\
\text { Ministry of Agriculture. }\end{array}$ & $\begin{array}{l}\text { Score based on size } \\
\text { of organic area }\end{array}$ & Organic area map \\
\hline $\begin{array}{l}\text { Average debt of } \\
\text { village }\end{array}$ & Average debt/year & $\begin{array}{l}\text { Score of average } \\
\text { debt/year }\end{array}$ & Debt map \\
\hline Acceptance of member & $\begin{array}{l}\text { Acceptance for adjustment of } \\
\text { organic agriculture to large } \\
\text { scale }\end{array}$ & $\begin{array}{l}\text { Score along with } \\
\text { acceptance }\end{array}$ & $\begin{array}{l}\text { Accepted map } \\
\text { (indicated by village } \\
\text { acceptance of large } \\
\text { scale organic } \\
\text { agriculture plot) }\end{array}$ \\
\hline
\end{tabular}

Table 3: Weighting score estimated by organic agriculture members through questionnaire with MCA

\begin{tabular}{|c|c|c|c|c|c|c|c|}
\hline & 1. Land use & 2. Soil & $\begin{array}{c}3 . \\
\text { Water } \\
\text { resource }\end{array}$ & $\begin{array}{c}4 . \\
\text { Transportation }\end{array}$ & $\begin{array}{c}5 . \\
\text { Organic } \\
\text { Area }\end{array}$ & $\begin{array}{c}6 . \\
\text { Debt of } \\
\text { village }\end{array}$ & 7. Acceptance \\
\hline 1. Land use & 0 & 3 & 3 & 2 & 3 & 3 & 3 \\
\hline 2. Soil & 3 & 0 & 3 & 1 & 3 & 3 & 3 \\
\hline 3. Water resource & 2 & 2 & 0 & 2 & 3 & 3 & 3 \\
\hline 4. Transportation & 3 & 2 & 3 & 0 & 3 & 3 & 3 \\
\hline 5. Organic area & 2 & 2 & 3 & 1 & 0 & 3 & 3 \\
\hline 6. Debt of village & 1 & 2 & 3 & 1 & 2 & 0 & 3 \\
\hline 7. Acceptance & 1 & 1 & 3 & 1 & 3 & 3 & 0 \\
\hline Sum & 12 & 12 & 18 & 8 & 17 & 18 & 18 \\
\hline Total & & & & & & & 103 \\
\hline Score & 0.12 & 0.12 & 0.17 & 0.08 & 0.17 & 0.17 & 0.17 \\
\hline
\end{tabular}

Multi-Criteria Analysis (MCA): Jovana et al., 2015, Langemeyer et al., 2018 and Mathias Vogdrup et al., 2019

Table 4: Weighting score averaged from various means

\begin{tabular}{|l|c|c|c|c|c|c|}
\hline \multirow{2}{*}{ Factor } & \multicolumn{2}{|c|}{ Review of relevant studies } & Questionnaire & Researcher & Weighting Score \\
\cline { 2 - 7 } & $\mathbf{( 1 )}$ & $\mathbf{( 2 )}$ & $\mathbf{( 3 )}$ & $\mathbf{( 4 )}$ & $\mathbf{( 5 )}$ & $\mathbf{( 6 )}$ \\
\hline 1. Land use & 0.09 & - & 0.130896 & 0.12 & 0.10 & 0.11 \\
\hline 2. Soil & 0.01 & 0.25 & 0.326998 & 0.12 & 0.17 & 0.17 \\
\hline 3. Water resource & 0.25 & - & 0.296936 & 0.17 & 0.18 & 0.23 \\
\hline 4. Transportation & - & - & 0.035088 & 0.08 & 0.06 & 0.06 \\
\hline 5. Organic area & - & 0.1 & - & 0.17 & 0.15 & 0.14 \\
\hline 6. Debt of village & - & - & - & 0.17 & 0.17 & 0.17 \\
\hline 7. Acceptance & - & - & 0.15 & 0.17 & 0.17 & 0.17 \\
\hline \multicolumn{1}{|c|}{ Total } & & & & 1.00 & 1.00 & 1.00 \\
\hline
\end{tabular}

(1) Liu, 2019 (2) Vogdrup-Schmidt et al., 2019 (3) Midatana et al., 2018 (4) Questionnaire: Score form participatory process of organic agriculture members (5) Score taken from the researchers' judgment (6) Average of each factor form (1) - (5) 
Table 5: Suitable scores for large scale of oranic agriculture plot

\begin{tabular}{|c|c|c|c|c|}
\hline Factor & Indicator & $\begin{array}{l}\text { Rating } \\
\text { score }\end{array}$ & $\begin{array}{l}\text { Weighting } \\
\text { score }\end{array}$ & Total score \\
\hline \multirow{5}{*}{ 1.Land use } & Water resource & 3 & \multirow{5}{*}{0.11} & 0.33 \\
\hline & Paddy filed & 3 & & 0.33 \\
\hline & Field crop & 2 & & 0.22 \\
\hline & Horticulture & 3 & & 0.33 \\
\hline & Forest Plantation & 1 & & 0.11 \\
\hline \multirow{6}{*}{ 2.Soil } & Soil Group 17 & 3 & \multirow{6}{*}{0.18} & 0.54 \\
\hline & Soil Group 18 & 2 & & 0.36 \\
\hline & Soil Group 20 & 1 & & 0.18 \\
\hline & Soil Group 22 & 3 & & 0.54 \\
\hline & Soil Group 35 & 1 & & 0.18 \\
\hline & Soil Group 36 & 1 & & 0.18 \\
\hline \multirow{3}{*}{ 3. Water resource } & $1,600-5,000 \mathrm{~m}^{3}$ & 3 & \multirow{3}{*}{0.22} & 0.66 \\
\hline & $600-1,600 \mathrm{~m}^{3}$ & 2 & & 0.44 \\
\hline & $250-600 \mathrm{~m}^{3}$ & 1 & & 0.22 \\
\hline \multirow{3}{*}{ 4.Transpotation } & $0-1 \mathrm{Km}$. & 3 & \multirow{3}{*}{0.04} & 0.12 \\
\hline & $1-3 \mathrm{Km}$. & 2 & & 0.08 \\
\hline & 3-7 Km. & 1 & & 0.04 \\
\hline \multirow{3}{*}{ 5.Organic Area } & $\begin{array}{l}>1,000 \text { Rai }(395.37 \\
\text { hectare) }\end{array}$ & 3 & \multirow{3}{*}{0.15} & 0.45 \\
\hline & $\begin{array}{l}\text { 300-1,000 Rai (118.61- } \\
\text { 395.37 hectare) }\end{array}$ & 2 & & 0.30 \\
\hline & $\begin{array}{l}\text { 1-300 Rai }(0.39- \\
\text { 118.61hectare })\end{array}$ & 1 & & 0.15 \\
\hline \multirow{3}{*}{ 6.Debt of village } & $\begin{array}{l}7,000,000-12,800,000 \\
\text { Baht }\end{array}$ & 3 & \multirow{3}{*}{0.02} & 0.06 \\
\hline & $4,000,000-7,000,000 \mathrm{Baht}$ & 2 & & 0.04 \\
\hline & $2,500,000-4,000,000 \mathrm{Baht}$ & 1 & & 0.02 \\
\hline \multirow{3}{*}{ 7.Acceptance } & Accept & 3 & \multirow{3}{*}{0.17} & 0.51 \\
\hline & accept but not ready & 2 & & 0.34 \\
\hline & pending & 1 & & 0.17 \\
\hline
\end{tabular}

Regarding the land suitability of large scale organic agriculture, it is considered on Land use type, soil quality, water resource in terms of flooding, transportation. Total suitable area was 275.79 hectare, where was classified as follows:

- The most suitable area (S3) was mainly occupied with paddy field consisted of soil suitable for agriculture at most, no problem of flooding in rainy season as the location was not very close to the water source, and access with various roads enabling transportation of agriculture products and goods.

- The moderate suitable area (S2) was mostly occupied with forest plantation, soil quality was moderate suitable for agriculture, no flooding in rainy season due to the location was not very near water source, and access road for transportation was not many as the S3 area.

- The least suitable area (S1) was mostly occupied with horticulture, soil quality was moderate to low suitable for agriculture, flooding area in rainy season, a few access roads for transportation,

Remarkably, the most suitable area (S3) was the largest category (151.82 hectare) where was much larger than the moderate suitable area (S2): 89.93 hectare and the least suitable area (S1): 34.05 hectare, being equivalent to $55.05 \%, 32.61 \%$, and $12.35 \%$ of total suitable area, respectively. 
However, by the means of suitable area for large scale organic agriculture map together with the standard of large scale and organic agriculture, the organic agriculture members were interviewed for the acceptance. Based on the most suitable area (S 3 ) of 151.82 hectare, it was accepted by only one village to be the organic agriculture of 20.64 hectare being equivalent to $13.59 \%$ of the most suitable area. This is due to the organic agriculture members could not implement the organic agriculture standard designated for an absolutely free of chemical use. Considering the large scale plot, the organic agriculture area of 20.64 hectare could not meet the standard of large scale plot designated for the area available as for equal or larger than 48 hectare. Therefore, at this step only the organic agriculture could be accomplished for 20.64 hectare but could not meet the large scale plot. In order to accomplish the purpose of large scale organic agriculture plot, the most suitable area should be considered for the target area because it occupied more than 48.00 hectare and had high potential to be an organic agriculture. Additionally, the UAV was employed for some part of the most suitable area, approximately 74.10 hectare. This UAV taken for the area where could meet the standard of large scale plot of 48 hectare, created the aerial photography of about 64.00 hectare.

In accordance with the organic agriculture standard, it requires the owner parcel map. Creating the owner parcel map on UAV was made to identify the land owners' right. With an integration approach of Geoinformatics and UAV Aerial photography in concurrence with stepwise method as well as participatory approach, the map of large scale organic agriculture plot could be transparently exhibited (Figure 4).

Moreover, the paddy field was the main Land use occupied area $(92.56 \%)$ as shown in Table 1, it is beneficial to establish the large scale organic rice field. As the potential area has already been existed by scoping for the most suitable area, it is not difficult to convince the organic agriculture members or other farmers on the benefit of large scale organic agriculture plot in terms of economic, social and environmental perspectives. The most suitable area of paddy field 151.82 hectare along the creek should be the target site for large scale organic agriculture.

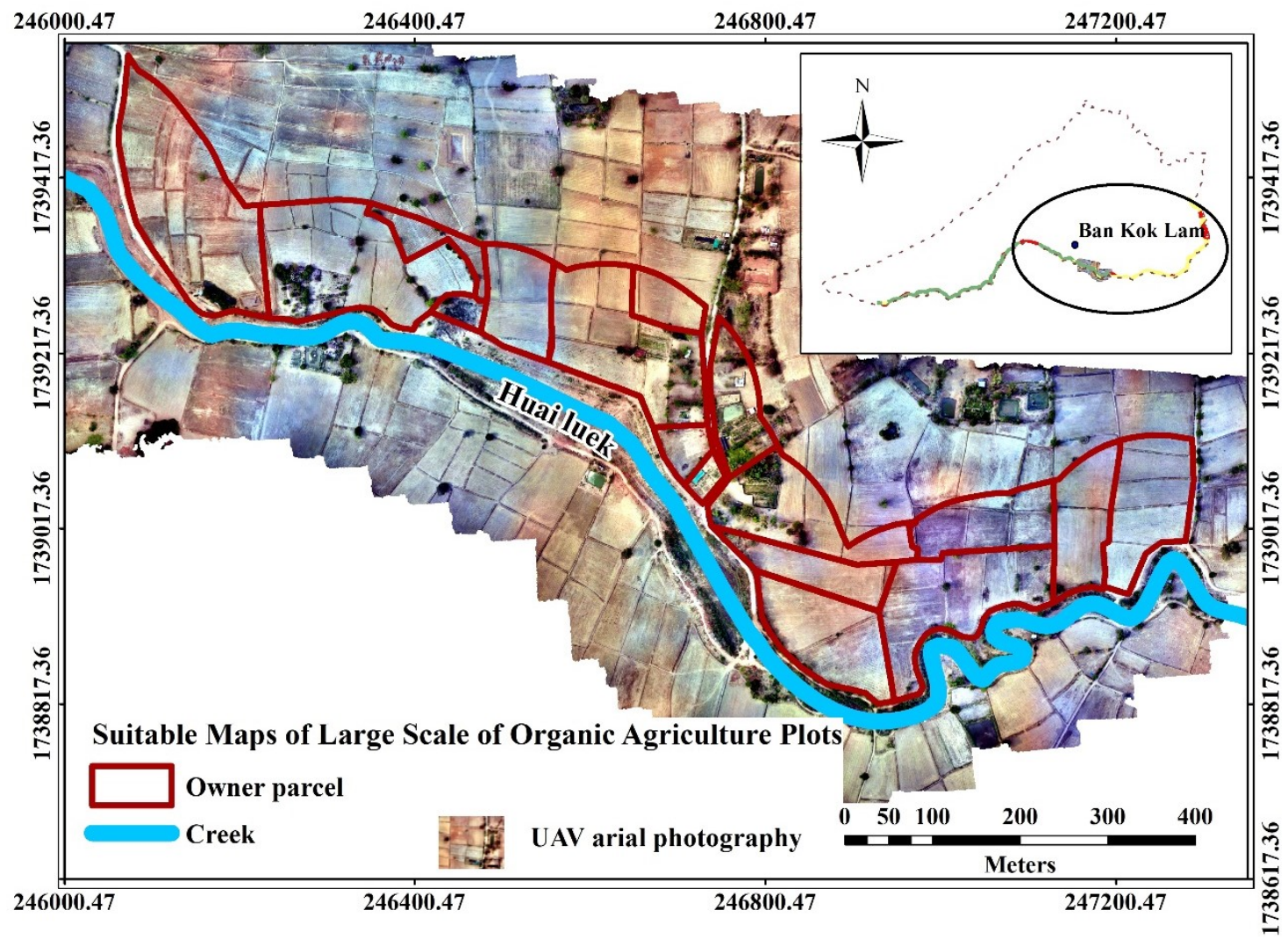

Figure 4: Maps of Suitable Large Scale Organic Agriculture Plot 


\section{Conclusions}

In accordance with the Four Year Development Plan (2017-2021) of Nong Wang Sok Phra Sub-District Administration Organization, Phon District, Khon Kaen Province, implementation of the organic agriculture pilot has been planned for the conventional agriculture area of 7 target villages along Huai Luek Creek. This study, therefore, focused an integration of Geoinformatics and Unnamed Aerial Photography (UAV) in order to assess the suitable large scale organic agriculture plot on the basis of large scale and organic agriculture standard.

Step by step of the study was performed, of which the outputs were subsequently produced as follows. The boundary and study area map were created using topography map and Georeferencing and Land use classification. Land use mainly consisted of the paddy field as for 630.83 hectare being equivalent to $92.56 \%$ of total Land use area (681.50 hectare). The study area with Land use map was validated by VDO record/ photography and field observation, indicating the conventional agriculture plot categorized as paddy field plot. Assessing the study area with Land use map as the conventional paddy field plot through QGIS created the potential suitable large scale organic agriculture area of 275.79 hectare consisting of the most suitable area of 151.82 hectare, the moderate suitable area of 89.93 hectare and the least suitable area of 34.05 hectare accounted as $55.05 \%$, $32.61 \%$, and $12.35 \%$ of total suitable area, respectively.

Focus group interview was appraised with the organic agriculture members for acceptance on the basis of the most potential suitable area of large scale organic agriculture plot together with the standard of organic agriculture and large scale. The most suitable area was accepted by only one village for transforming to the organic agriculture of 20.64 hectare. The weak acceptance was principally considered on the absolutely free chemical use standard of organic agriculture. Nonetheless, the large scale could not be attained due to the area was not 48 hectare of the large scale standard. In order to expand the organic agriculture area to meet both organic and large scale standard, UAV/UAV Imagery with parcel maps was performed to create the suitable large scale of organic agriculture map. Comparing to the most suitable agriculture area of 151.82 hectare, it was accepted to be organic agriculture of 20.64 hectare, where was only $13.60 \%$. However, the organic agriculture map created through digital technology, Geoinformatics and UAV was the apparent maps that enable the organic agriculture plot's members and non- members perception towards organic agriculture and large scale plot. The organic agriculture area can be expand to meet the large scale criteria (48 hectare) by coping with the most suitable area of 151.82 hectare.

\section{References}

Annosi, M. C., Brunetta, F., Monti, A., Nat, F., 2019, Is the Trend Your Friend? An Analysis of Technology 4.0 Investment Decisions in Agricultural SMEs. Computers in Industry, Vol. 109, 59-71.

Chapin, Jr., F. S. and Kaiser, E. J., 1979, Urban Land Use Planning, 2nd Edition. University of Illinois Press, Chicago.

Coda, J., Gomez, D., Steinmann, A. R. and Priotto, J., 2015, Small Mammals in Farmlands of Argentina: Responses to Organic and Conventional Farming. Agriculture, Ecosystems \& Environment, Vol. 211,17-23.

Bureau of Occupational and Environmental Diseases, 2018, Report of Occupational and Environmental Diseases 2017 [online]. [cited 2018, 30 November]. Available: http://envocc.ddc.moph.go.th/contents/view/669.

Department of Lands Headquarters, Ministry of Interior, 2016, [online]. [cited 2018, 25 November]. Available: http://dolwms.dol.go.th/tvwebp/.

Langemeyer, J., Palomo, I., Baraibar, S., GómezBaggethun, E., 2018, Participatory MultiCriteria Decision Aid: Operationalizing an Integrated Assessment of Ecosystem Services. Ecosystem Services, Vol. 30: 49-60.

Liu W, Zhan J, Zhao F, Yan H, Zhang F, Wei X., 2019, Impacts of urbanization-induced land-use changes on ecosystem services: A case study of the Pearl River Delta Metropolitan Region, China. Ecological Indicators, Vol.98: 228-238.

Martínez-Carricondo, P., Agüera-Vega, F., Carvajal-Ramírez, F., Mesas-Carrascos, F. J., García-Ferrer, A. and Pérez-Porras, F. J., 2018, Assessment of UAV-Photogrammetric Mapping Accuracy Based on Variation of Ground Control Points. International Journal of Applied Earth Observation and Geoinformation, Vol. 72, 1-10.

Ministry of Agriculture and Cooperatives., 2016, Manual for large-scale agricultural extension system implementation, [online]. [Cited 2018, 1 November].Available: http://www2.oae.go.th/EVA/ download/success/large_scale.pdf 
ational Statistical Office of Thailand, Ministry of Digital Economy and Society, 2004, [online]. ][Cited 2018, 25 November]. Available: 2018, 31 August http://statbbi.nso.go.th/staticreport/page/sector/th/08.aspx.

Nong Wang Sok Phra Sub-District Administration Organization, Phon District, Khon Kaen Province, 2018, 4 year Development Plan (20172021) [online] [cited 2019, 22 January]. Available: http://www.nongwaeng-kk.go.th/ userfiles/lawfile/11340181024681.5018.doc

Midatana, S., Saran, S. and Ramana, K. V., 2018, Site Suitability Analysis for Industries Using GIS and Multi Criteria Decision Making. ISPRS Ann Photogram Remote Sens. Spatial Inf. Sci., Vol. 15, 447-54.

Riwthong, S., Schreinemachers, P., Grovermann, C. and Berger, T., 2017, Agricultural commercialization: Risk Perceptions, Risk Management and the Role of Pesticides in Thailand. Kasetsart Journal of Social Sciences, Vol. 38(3): 264-72.
Schreinemachers, P., Chen, H., Nguyen, T. T. L., Buntong, B., Bouapao, L., Gautam, S., Le, N. T., Pinn, T., Vilaysone, P. and Srinivasan, R., 2017, Too Much to Handle? Pesticide Dependence of Smallholder Vegetable Farmers in Southeast Asia. Science of the Total Environment, Vol. 470-477.

Tahar, K. N., 2013, An Evaluation On Different Number of Ground Control Points in Unmanned Aerial Vehicle Photogrammetric Block. ISPRS International Archives of the Photogrammetry, Remote Sensing and Spatial Information Sciences, Vol. XL-2/W2: 93-98.

Vogdrup-Schmidt, M, Olsen, S. B., Dubgaard, A., Kristensen, I. T., Jørgensen, L. B., Normander, B., Ege, C. and Dalgaard, T., 2019, Using Spatial Multi-Criteria Decision Analysis to Develop New and Sustainable Directions for the Future use of Agricultural Land in Denmark. Ecological Indicators, Vol.103, 34-42. 